\title{
NEW INVESTMENT: AN EXPLORATORY CASE STUDY OF THREE MATURE EDINBURGH FESTIVALS AND THEIR FUTURE FUNDING OPPORTUNITIES
}

\author{
KUAN-WEN LIN,* PATRICK STEIN, $\dagger \uparrow \S$ and JOE GOLDBLATT* \\ *International Centre for the Study of Planned Events, Queen Margaret University, \\ East Lothian, Scotland, UK \\ $\dagger$ Free University of Berlin, Berlin, Germany \\ $\$$ Fachhochschule für Oekonomie \& Management (FOM), \\ Berlin University of Applied Sciences, Berlin, Germany \\ §PricewaterhouseCoopers, Berlin, Germany
}

\begin{abstract}
This article examines how festival holding organizations (FHOs) may identify emerging sources of alternative financing from banks, venture capitalists, and venture philanthropic organizations. The research includes both quantitative analysis of 10 years of economic data from festivals in Edinburgh, Scotland and qualitative interviews with a leader in both the banking and cultural community. The research concludes that there is a growing need for FHOs to identify new sources of funding beyond that historically provided by the public sector or earned income such as ticket sales and that a combination of banks, venture capital firms, and venture philanthropic organizations may provide valuable alternative funding sources in the future.
\end{abstract}

Key words: Festivals; Banks; Venture capital; Venture philanthropy; Commercial; Not for profit; Principal-Agent theory; Grants

Introduction

According to Getz, Andersson, and Larson (2007) and other scholars (Festival Fringe Society Limited, 2006a; Jones Economics, 1996) cultural festivals are employed as tourism catalysts by the hosting municipalities and account for positive economic impacts in host locations. Festival Holding Organizations (FHOs) are the organizations that are in charge of and are financially responsible for operating festivals. However, due to the not-for-profit structure existing in the majority of FHOs, there are significant differences in the financial management and business organizational behavior theories between traditionally commercial businesses and not-for-profit festival organizations. Because there is a trend showing that the traditional funding resources for festivals are un-

Address correspondence to Kuan-wen Lin, International Centre for the Study of Planned Events, The School of Business, Enterprise, and Management, Queen Margaret University, Edinburgh, Queen Margaret University Drive, Musselburgh, East Lothian, EH21 6UU, Scotland, UK. Tel: +44 (0)131 474 0000; E-mail: klin@qmu.ac.uk 
der pressure, there is a strong and immediate need to modify well-developed commercial theories to fit the operational environment of not-for-profit festivals (Finkel, Goldblatt, \& Lin, 2009; Lin, 2008). Specific theories with practical applications for festivals should be cultivated to close these funding gaps, and so create greater opportunities for financial sustainability. Moreover, although these investment and finance models have been adopted and well developed in the commercial world, they are often difficult to access by not-forprofit festival holding companies.

\section{Methodology}

This study incorporates quantitative and qualitative research methodology and includes secondary data analysis of the three major Edinburgh Festivals (Edinburgh International Festival; Edinburgh Festival Fringe; Edinburgh Military Tattoo) as well as an interview with a leading expert in both the financial and festival fields. The expert interviewed for this study is Lady Susan Rice, CBE who was Chairman and Chief Executive of Lloyds TSB Scotland, a leading UK bank, and has chaired the Edinburgh International Book Festival since 2001 and the Edinburgh Festivals Forum since 2008. Under her stewardship, Lloyds TSB Scotland sponsored many art and cultural organizations such as the Edinburgh International Festival.

This study also investigates the organizational behavior of not-for-profit cultural festivals using the Principal-Agent theory. The aim of this exploratory investigation is to establish baseline research in this field and promote the advancement of future funding and investment opportunities for festivals.

Three mature, major cultural festivals in Edinburgh (Edinburgh International Festival; Edinburgh Festival Fringe; Edinburgh Military Tattoo) are explored through this research. These festivals have been recognized as representatives of international preeminent cultural festivals with high potential for further development (AEA Consulting, 2006; Department for Culture, Media and Sport [DCMS], 2001a). The not-for-profit organizational structure developed by these festivals has been adopted by many destinations and organizations around the world as a model for developing festivals (Edinburgh International Festival [EIF], 2009; Wu, 2002). Within this model, three main income streams support a not-for-profit festival: public grants, sponsorship, and box office income (Lin, 2008). However, in the climate of the 2009 global economic recession and the expected tightening of public grants, many festival specialists are aware that alternative funding sources should be explored for their future sustainability (Finkel et al., 2009).

\section{Background}

Since 2001, the UK government has made cultural festivals a priority. They are considered as important showcases for the performing arts and are a crucial element of the creative industries. The report "Creative Industries Mapping Documents" disclosed that a turnover of $€ 5.7$ million was generated by the Edinburgh International Festival (EIF) and 400,000 tickets were sold by the Edinburgh Festival Fringe (Fringe) in 1999 (DCMS, 2001a). Moreover, in 2008 the budget for EIF increased to approximately $€ 9$ million, and the Fringe in 2009 established a new record by selling 1,850,000 tickets (Carrell, 2009, EIF, 2008). As an important member of Edinburgh's Summer Festivals portfolio, the Edinburgh Military Tattoo (Tattoo) has enjoyed almost 10 years of sell-out programs, selling approximately 220,000 tickets each year (Edinburgh Military Tattoo, 2009). These cultural events have generated strong business opportunities in Edinburgh while fulfilling their historic mission of providing "a platform for the flowering of the human spirit” (EIF, 2009).

\section{Research Purpose and Questions}

This study examines alternative and diverse forms of finance for not-for-profit cultural festivals. Three research questions are examined to identify potential new sources of alternative funding for these organizations. First, what new alternative finance options are available to FHOs? Second, what barriers currently exist to accessing these options? Third, what may the cultural sector and financial services industries do to help overcome these barriers? 


\section{Not-for-Profit Organizations in Festivals}

Getz (2002) states that in most cases the organizers of festivals are not-for-profit societies with members. Lin's research (2008) for the major cultural festivals in Edinburgh confirms this point of view, with 10 of the 12 festivals in this study being registered charities. Caves (2000) considers that one of the reasons why not-for-profit organizations are typical in festivals is the high fixed cost associated with the creative-goods markets. Not-for-profit organizations "take over where profit-seeking enterprises cannot cover their fixed costs" (Caves, 2000, p. 225). He states that nonprofit organizations have the ability to adopt a two-part charge, "customers pay a fixed or membership fee plus a unit charge for each ticket or use of the facility," and therefore these organizations enjoy advantages that help to explain their prevalence in the creative industries (Caves, 2000, p. 226). Moreover, he states that conventional profit-seeking enterprises may not generate maximum social benefits because "they might charge too much, settle for inferior quality, or fail to produce some creative goods at all" (Caves, 2000, p. 247). Getz (2002) states that festivals are often "not-for-profit in nature" (p. 217) and dependent on external sources of funding and other resources.

Goldblatt (2008) explains that because of the different objectives of the event organizations, they adopt varying financial philosophies. There are three main categories in financial philosophies of festival holding organizations: profit-oriented events; break-even events; and loss leaders or hosted events. The different financial philosophies between a charitable endeavor event and that of a commercial venture are very different. From the limited evidence of the case studies, it is suggested that festivals owned by the private sector "will not carry them for very long if they do not make a profit" (Getz et al., 2007, p. 120). However, nonprofit organizations "seem to possess social capital through their networks and charitable status that enables some of them to continue to raise money, produce the event, and sell tickets even when they are financially very weak" (Getz et al., 2007, p. 120).

Based on the context of nonprofit organizations and the creative industries, Caves (2000) stresses the key point of financial management in festivals: total revenues should equal total costs. Nonprofit organizations cannot "stay in the game" without covering the total costs (Caves, 2000, p. 225). In addition, due to the lack of guaranteed base funding for the festivals, Getz et al. (2007) consider that inadequacy of resources is always a threat to the survival of festival organizations. Caves (2000) observes that nobody in not-for-profit organizations has either the obligation to make up a loss or the right to gain an unanticipated profit; the bankruptcy alarm may go out to sponsors, but they are "normally not committed to serve as guarantors" (p. 234). This may result in the generation of only short-term funding, and no long-term commitment.

Nevertheless, as Getz et al. (2007) mention in their study, all financial crises in festivals "have direct consequences for stakeholders, such as artists and suppliers not getting paid, sponsors losing goodwill, and customers being disappointed" (p. 119). The unwary creditor may suffer from the bad debt of a besieged not-for-profit organization. However, this is not the perspective in the creative industries, especially in performing arts organizations who tend to think that government subsidies (or donors) will come forward to close the gap between revenue and costs when these organizations suffer from financial problems, in order to maximize any wider social benefits (Caves, 2000).

The financial crisis in festivals may be relieved by key stakeholders such as governments, who are therefore valuable partners, especially in turbulent times. For example, Getz et al.'s study (2007) discovered that the Arvika Festival in Sweden "was bailed out by the municipality in the first years when they failed to balance their budget" (p. 119).

\section{Funding Challenges}

"Times have changed. Governments are in trouble. We could benefit from finding alternative funding methods for cultural events"-Local council member in Scotland (Finkel et al., 2009, p. 9).

As fundraising and applying for public grants has become more competitive in recent years, it has been suggested that diversified and alternative financial resources should be pursued by festivals (Finkel, 2009). In Finkel et al's (2009) a list of 
funding options for FHOs is explored and options range from donor, funder, and purchaser to consumer. However, these options are very different from commercial organizations, which traditionally pursue a range of funding options, from equity capital to debt financing instruments. There appears to be a reticence by commercial banks in the application of their credit activities and by private venture capitalists to invest in festivals. This issue has also been further confirmed by an examination of the financial statements of the EIF, the Fringe, and the Tattoo. Moreover, one of the Edinburgh Festivals' directors stated that its commercial sponsorship was currently the only targeted relationship that exists between banks and the festival (Finkel et al., 2009).

Blackburn, Stokes, and Wilson (2001) in their research report to the UK Government stated that financial institutions such as banks and venture capitalists have insufficient understanding of the creative industries, which is a crucial limiting issue in the further development of this sector. Our research here tries to explore opportunities for closing this gap.

Thus, as the first step in this research, Figure 1 , based on an analysis of the comprehensive theoretical frameworks of Creative Industries, has been created to describe the current industrial characteristics of the festival industry in Edinburgh from a financial perspective (Caves, 2000; DCMS, 2001a, 2001b). A triangular structure is presented in order to illustrate the number and distribution of the activities and the jobs created within this system.

From Figure 1 it may be seen that most notfor-profit FHOs provide a type of social welfare service rather than a commercial service. For example, the EIF is registered as a charity organization that seeks to break even financially every year (EIF, 2009). A low or competitive ticket price policy is used to achieve its objectives, "actively ensure equal opportunities for all sectors of the Scottish and wider public to experience and enjoy the Festival" (EIF, 2006). Lady Rice, who was Chairman and Chief Executive of Lloyds TSB Scotland and chairs the Edinburgh International Book Festival and the Edinburgh Festivals Forum (personal interview, August 19, 2009), also states that the book festival carefully considered raising individ- ual event ticket prices and the decision to have no overall entrance fee. As a result of this decision, attendance increased as did the surplus and this change in pricing was considered a successful outcome. This leads to the creation of a breakeven point in Figure 1 that explains the FHOs' ultimate goal (or Holy Grail, as one festival executive described it).

Cultural festivals also play an important role in fostering a cluster of regional industry development opportunities. Figure 1 depicts the interlocking relationship between FHOs and related industries and activities, and confirms the findings of DCMS (2001a). The DCMS study found that in the creative industries a strong commercial sector is matched with a grant-dependent sector, and has been called "the inter-dependency of the "not-forprofit' and the 'for-profit' sector" relationship in creative industries (DCMS, 2001b). Carlsen, AliKnight, and Robertson (2008) found that the development of festivals in Edinburgh has created an influx of specialist staff more able to deliver festivals and events. This has brought a diversity of skills and ideas to the city, thus enhancing the cultural products and their quality. Cultural festivals may serve as a magnet to retain a sufficient number of members of the creative class to stay in a geographical area such as Edinburgh. Florida (2002) states that this is key for destinations to win "the war for creativity" (p. 52) in this era.

\section{Principal-Agent Theory}

Previous researches regarding Principal-Agent theory have been developed by Jensen and Meckling (1976), Ross (1973), Stiglitz (1974), and Wilson (1968). The relationship of principal-agent is one of the oldest models of social interaction (Ross, 1973). In law, a relationship of agency exists between at least two parties: the agent and the principal (Ross, 1973). In this study, the banks, venture capitalists, or venture philanthropists (Banks, VCs, and VPs) are defined as the principal and the FHOs as the agent (for an agency analysis in venture capital investment; see Reid, 1998). The original focus of Agency theory is the resolution of two problems. The first is the agency problem, that may arise on the one hand through the different goals of the principal and agent (also called 


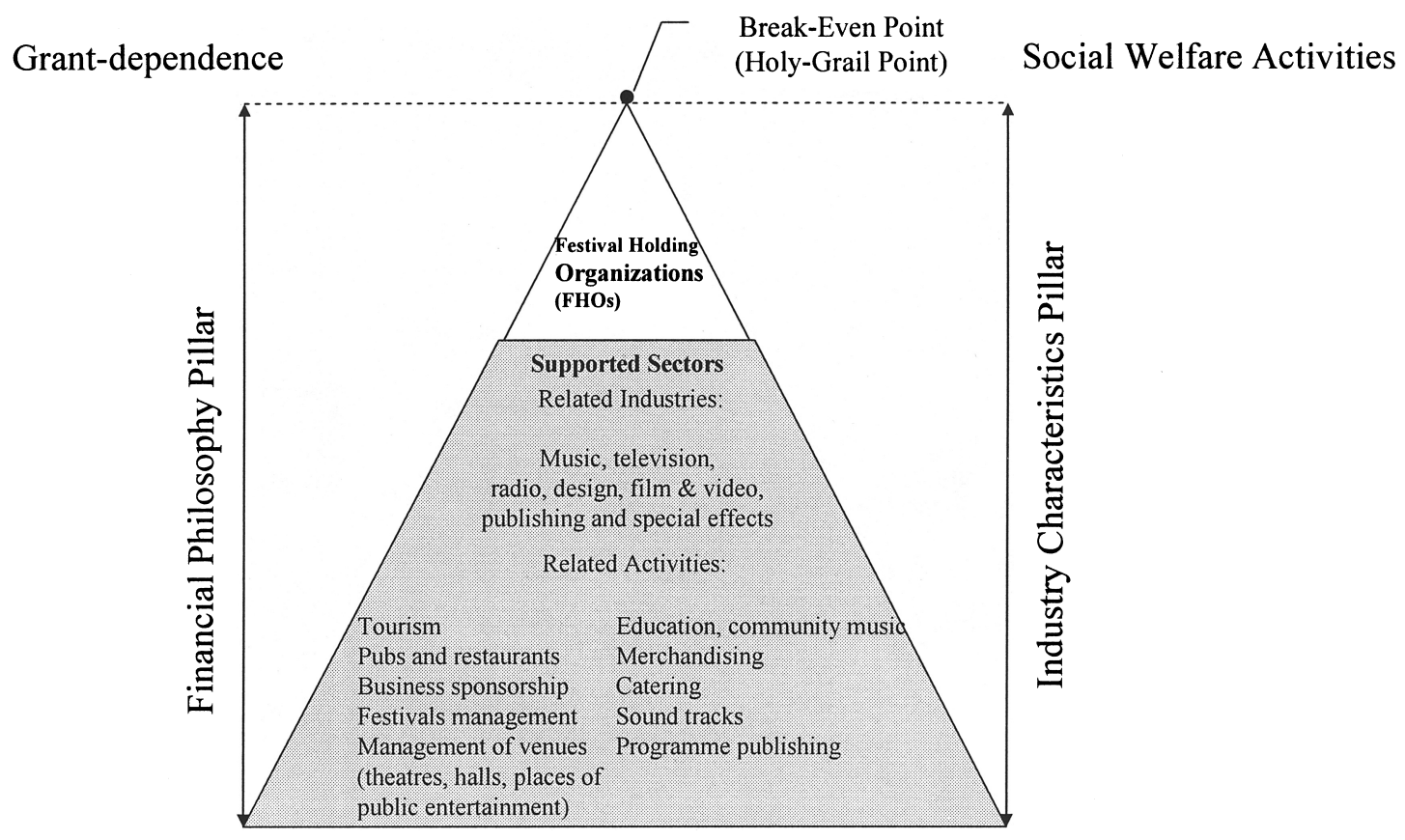

Profit-seeking

Commercial Activities

Figure 1. Lin-Stein-Goldblatt cultural festival industry ecology.

external effects) and on the other hand through the difficulty for the principal to verify and to observe what the agent is actually doing (also called asymmetric information) (Eisenhardt, 1989; Spremann, 1987). External effects mean that the decision of the FHO does not only impact their own concern for a good performance of the festival, but also the concern to maximize the requirements of the investors and creditors. The information is asymmetric because the investors and creditors do not know or control the decisions of the FHO. Therefore, for example, when the FHO management makes an unfavorable decision against maintaining a surplus (e.g., to raise staff salary with no valid reasons), the investors and creditors may suffer losses.

The second issue is that of risk sharing, when the principal and agent have different risk preferences (Eisenhardt, 1989; Grossman \& Hart, 1983). For example, if the venture capitalist is risk neutral with regard to maximizing the direct financial gains (i.e., Return on Investment) and the management of FHO is risk adverse. In this case, the man- agement of the FHO would not manage the festival so as to maximize the direct financial gains for the venture capitalist.

Under these scenarios, both the agent and principal display independent utility function, which they try to maximize and then find the Pareto-efficient arrangements. Pareto-efficiency is a reached condition, where one of the parties cannot improve their circumstances without degrading the circumstances of the other party (Ross, 1973). The aim for the creditors and investors is that the FHO works to obtain reimbursement or maximize ROI, whereas the creditors and investors have to incur costs monitoring (monitoring costs) the FHO (Cochrane, 2005). First, the creditors and investors may pay the capital by tranche (in part) if the FHO reaches an agreed milestone. Second, the FHO may give a signal (e.g., financial and budgeting reports) to guarantee that they will not harm the principal and will reach the principal's financial expectations. These costs for the agent are called bonding costs. The third kind of cost is residual costs. These are the divergence between the agent's 
operation decision and the decision to maximize the concern of the principal (Fama \& Jensen, 1983). The monitoring, bonding, and residual costs are unavoidable in the context of the agency relationship. However, for both the principal and agent, it is an advantage to minimize the agency costs (Jensen \& Meckling, 1976).

Figure 2 depicts the principal-agent relationship with both the signaling of the FHO and the monitoring of the investors and creditors. Based on the theory, an economic system is needed to fund FHOs so as to determine the external and internal factors that influence the decision of the investors and creditors and the risks and rewards they have in their contract.

\section{Financial Management Within Festivals}

"It is unrealistic to think that Scotland wants a world-class set of festivals without world-class funding to support them ... The world is catching up!"-Cultural events director in Scotland (Finkel et al., 2009, p. 10).

\section{The Edinburgh International Festival (EIF)}

The Edinburgh International Festival Society, which is a charitable company limited by guarantee, is responsible for producing the EIF. There is no shared capital within this organization and each member has responsibility to contribute only one pound if a deficit occurs (EIF, 2006). The EIF financial philosophy is outlined in the official web- site: the not-for-profit organization intends to cover its costs each year, while the finest performers and creators around the world are invited by the Festival Director to present their works during 3 festival weeks (EIF, 2009).

Miller (1996) explores in "The Edinburgh International Festival 1947-1996।," the longitudinal financial statistical performance of this hallmark event, and demonstrates that in the first 40 years, there were only 10 years in which the festival produced a surplus (25\%); however, there were 4 years with a surplus from 1986 to 1996 (40\%). This suggests that in the last decade of the previous 50 years, the possibility of the festival being operated with a cash surplus has risen from $25 \%$ to $40 \%$ (Lin, 2008).

Table 1 depicts where the EIF income has come from in recent years. From this table it is obvious that public grants have an important role to play in the EIF income structure.

From the data Lin (2008) provided, the average public grants ratio of the EIF from 1997 to 2006 is $34.26 \%$. Therefore, it is arguable that if more public grants are given, festival operations might improve. Nevertheless, Lin (2008) examines 77 sets of financial data from eight of the major festivals under the Festivals Edinburgh umbrella from 1997 to 2006 and this study revealed that there was no statistically significant association between the financial results and the public grants ratio among these financial figures. This suggests that direct public funding could not effectively help

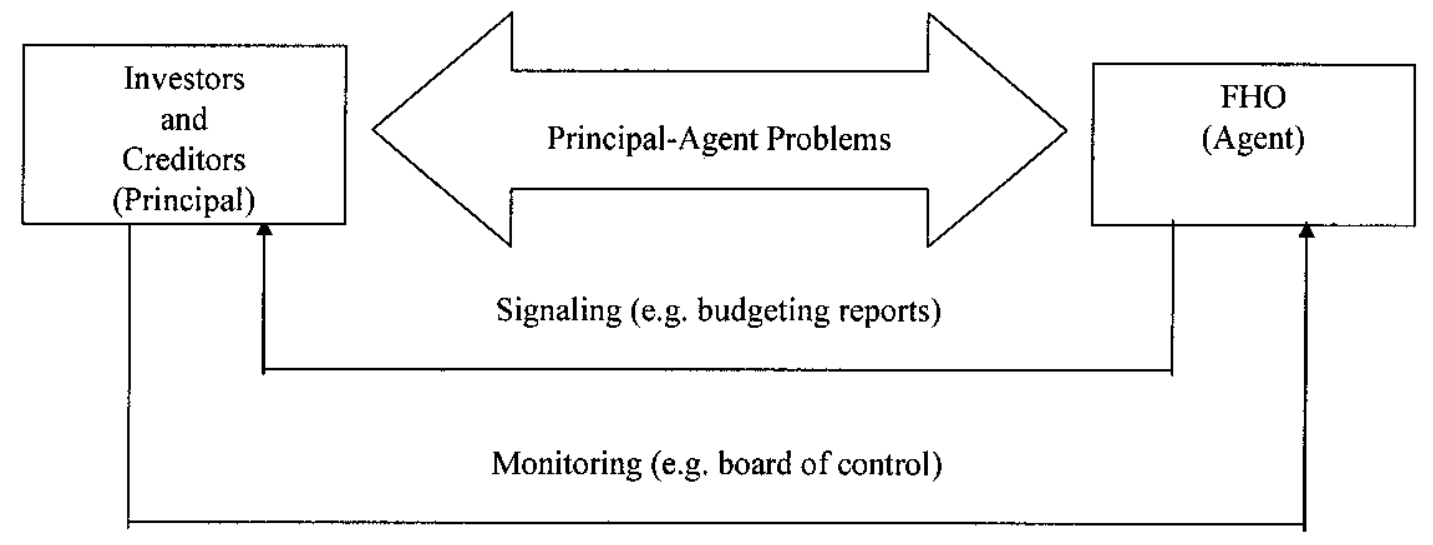

Figure 2. Principal (investors and creditors)-agent (FHO) relationship. 
Table 1

The EIF Income Structure

\begin{tabular}{lccc}
\hline Income ResourcelYear & 2008 & 2007 & 2006 \\
\hline Ticket sales & $48 \%$ & $26 \%$ & $26 \%$ \\
Sponsorship and donations and other earned income & $52 \%$ & - & $35 \%$ \\
Public grants & $52 \%$ & - & $39 \%$ \\
\hline
\end{tabular}

festivals' ability to control or improve their financial performance.

The EIF financial instruments demonstrate that there were only small amounts of bank overdraft compared with its $€ 10,000,000$ annual budget. This is shown in the balance sheet and through several outside funds providing repayable loans to the EIF in order to cover any short-term cash flow needs (EIF, 2006). However, long-term and sustainable loans are noticeably absent through the analysis. As a result, the EIF may be financially vulnerable, once central and local government funding is reduced, even though it has been very successful in its artistic mission.

\section{The Edinburgh Festival Fringe}

The Edinburgh Festival Fringe is the largest arts festival in the world with over 20,000 performers and 3,000 individual productions each August. In 1958 the Edinburgh Festival Fringe Society was established to coordinate all of the productions on offer during the 3 weeks of the festival in August in Edinburgh (Festival Fringe Society Limited, 2009). The Edinburgh Festival Fringe is different from the EIF in that there is no artistic vetting of the Fringe's programs and anyone is welcome to participate in the festival once they have found a venue. The Edinburgh Festival Fringe Society provides information, a central box office, and a published program of all productions. Each of the individual productions is responsible for their own financial operations and for the fee payable to the Fringe. However, the Edinburgh Festival Fringe Society is a charitable company limited by guarantee (Festival Fringe Society Limited, 2009).

Compared to the EIF, as seen in Table 2, the Edinburgh Festival Fringe receives comparatively low levels of public funding. From the data Lin (2008) examined, the average public grants ratio of the Edinburgh Festival Fringe is 5.64\% during the entire period 1997 to 2006 . However, the Edinburgh Festival Fringe financial statement disclosed that not only was City of Edinburgh Council the landlord of the Fringe premises under a lease agreement, but it also provided a loan to finance a property for the Fringe over 20 years. Furthermore, the two major events organized by the Fringe-The High Street and Fringe Sunday were managed in association with the City Council's major event planning group (Festival Fringe Society Limited, 2006b).

In addition, Lin's study (2008) reveals that from 1997 to 2006, 40\% of the Edinburgh Fringe Festivals (the FHO) were run at a deficit. The limited reserves of this organization, in contrast to the overall scale of the event, make this organization financially vulnerable. For example, in 2008, an operational crisis resulting from the installation of new ticketing software at the Edinburgh Festival Fringe required between $€ 300,000$ and $€ 600,000$ to continue operations (Carrell, 2009, Dibdin, 2008). The ticketing catastrophe also led to the resignation of the Edinburgh Festival Fringes' new director.

\section{The Edinburgh Military Tattoo}

The first Edinburgh Military Tattoo took place in 1950 and has continually attracted the world's best massed pipes and drums to participate in this internationally renowned tourism event. The Tattoo is set up and run for charitable purposes and has been recognized as one of Britain's most spectacular outdoor events. The annual audience averages 217,000 and around 100 million people see the Tattoo dramatically staged in front of historic Edinburgh Castle on international television each year (Edinburgh Military Tattoo, 2009).

Although they have the full support of the City of Edinburgh Council and authorization from The 
Table 2

Edinburgh Festival Fringe Income Structure

\begin{tabular}{lccc}
\hline Income ResourcelYear & 2006 & 2005 & 2004 \\
\hline Trading and investment incomes and other incomes & $75.7 \%$ & $78.3 \%$ & $72.6 \%$ \\
Sponsorship and donation & $21.3 \%$ & $18.3 \%$ & $22.0 \%$ \\
Public grants & $2.9 \%$ & $3.4 \%$ & $5.4 \%$ \\
Total income resources & $£ 1,878,946$ & $£ 1,513,326$ & $£ 1,413,213$ \\
\hline
\end{tabular}

Ministry of Defense and HQ 2nd Division, the Tattoo received no public grants to hold the event (Edinburgh Military Tattoo, 2006, 2004; Lin, 2008). For many years the Tattoo tickets have been sold out in advance within just a few weeks of trading and this has helped the company to generate a strong surplus. Moreover, this has also given the Tattoo the ability to gift some $€ 5$ million to other service and civilian organizations in Scotland over the years (Edinburgh Military Tattoo, 2009). However, the detail of the Tattoo's income structure is not accessible, although through the disclosure of its financial statements it has fulfilled the requirement of related UK regulations (Edinburgh Military Tattoo, 2006; Edinburgh Military Tattoo Charities, 2001).

Through the analysis of these three mature festivals in Edinburgh, there is at least one for-profit subsidiary that is $100 \%$ owned by each of the charitable parent organizations in each festival. Each FHO operates a retail outlet and undertakes sale activities in connection with goods related to the festivals and then submits the majority of their profit as gift aid, a tax-effective way of giving, to the parent charitable organization. However, the official website of the Edinburgh Military Tattoo claims that the recipient of this profit is the Edinburgh Military Tattoo (Charities) Limited, a forprofit subsidiary of the charity, which is in fact for all practicable purposes the main operator of the festival. This, defacto for profit organization, donates the surplus to the charitable parent organization, which then provides additional funding to other charities including the Edinburgh Festivals (Edinburgh Military Tattoo, 2006; Edinburgh Military Tattoo Charities, 2001).

Based on the financial analysis of these three festival holding organizations, an input-output model of festival organization has been created and is depicted in Figure 3. This model demonstrates the main input and output factors of the festival holding organizations and the various roles of potential investors and creditors. The model also depicts the source of their capital to invest in the organizations and the payback necessary to achieve adequate return on investment.

\section{FHO Funding Alternatives}

As a result of this previous analysis it is possible to investigate several creative and alternative financial funding opportunities for FHOs. Therefore, we will focus here on the consideration of two types of financing: funding from banks and from venture capital firms and will further analyze the funding structure of these two very different types of institutions (Winton \& Yerramilli, 2008).

Banks belong to a traditional part of financing (especially as creditors), but they are not investors (Benjamin \& Margulis, 2005). This means that FHOs may receive money from the bank as a loan to invest in services or goods for the festival. There are two main types of banks: local and national. The first type is a bank located in the local municipality and they generally know their customers and market area as well as the operations of the festival. However, the national bank is a bank that serves a wider geographic area such as an entire country and they generally may not be familiar with the local conditions. The difficulty is that investment policies are developed at Headquarters level, and may not help to support local investment decision. It is generally easier for the FHO to obtain funds from the local bank rather than from the national bank. Therefore, joint ventures between different (local and national) banks are a potential structure for providing funding from banks to FHOs. 
Another new and innovative possibility for financing FHOs is venture capital funding. Venture capital funding is a financial service from professional organizations in which they assess business opportunities, provide capital, and assist the firms in managing its portfolio (Bloomfield, 2005; Kenney, Haemmig, \& Goe, 2008). The general purposes of venture capital firms can fall into the following three major categories: initiation of trading (start-up), change of market position (development capital), or changing of ownership (buy-out). For example, mature festivals may qualify as being in need of development capital, as a type of microfinance, because the events (especially the case studies in this article) have been in operation for a longer period of time and the event organizers may seek alternatives to traditional financing. A number of types of VCs have been investigated to identify the different types of finance potentially available for festivals, these include: public and private international venture capital firms, smallbusiness investment companies (SBICs), and corporate venture capital divisions.

Public and private international venture capital firms are usually organized as limited partnerships and receive capital from venture capital themselves. SBICs had the task of stimulating longterm debt and equity investment in small business (Dana, 2008; Sherman, 2005). Corporate Venture Capital Divisions are established by large corporations in the hope of funding small companies that have resources that other large companies want or need (Bloomfield, 2005).

There are a number of ways by which FHOs can fund festivals with banks and venture capital organizations. Lady Rice (personal interview, August 19, 2009) suggests that VC funding could be effective for certain aspects of festivals. In the context of the Input-Output model (Figure 3), the traditional source for finance (e.g., to pay for the venue, performance groups, equipment companies) for festivals is government and private sector grants, ticket sales, loans, sponsorship, concessions, and merchandising.

Figure 4 depicts the critical path a festival manager may need to navigate and achieve in order to receive funding from a Principal.

In the financial planning cycle, the festival

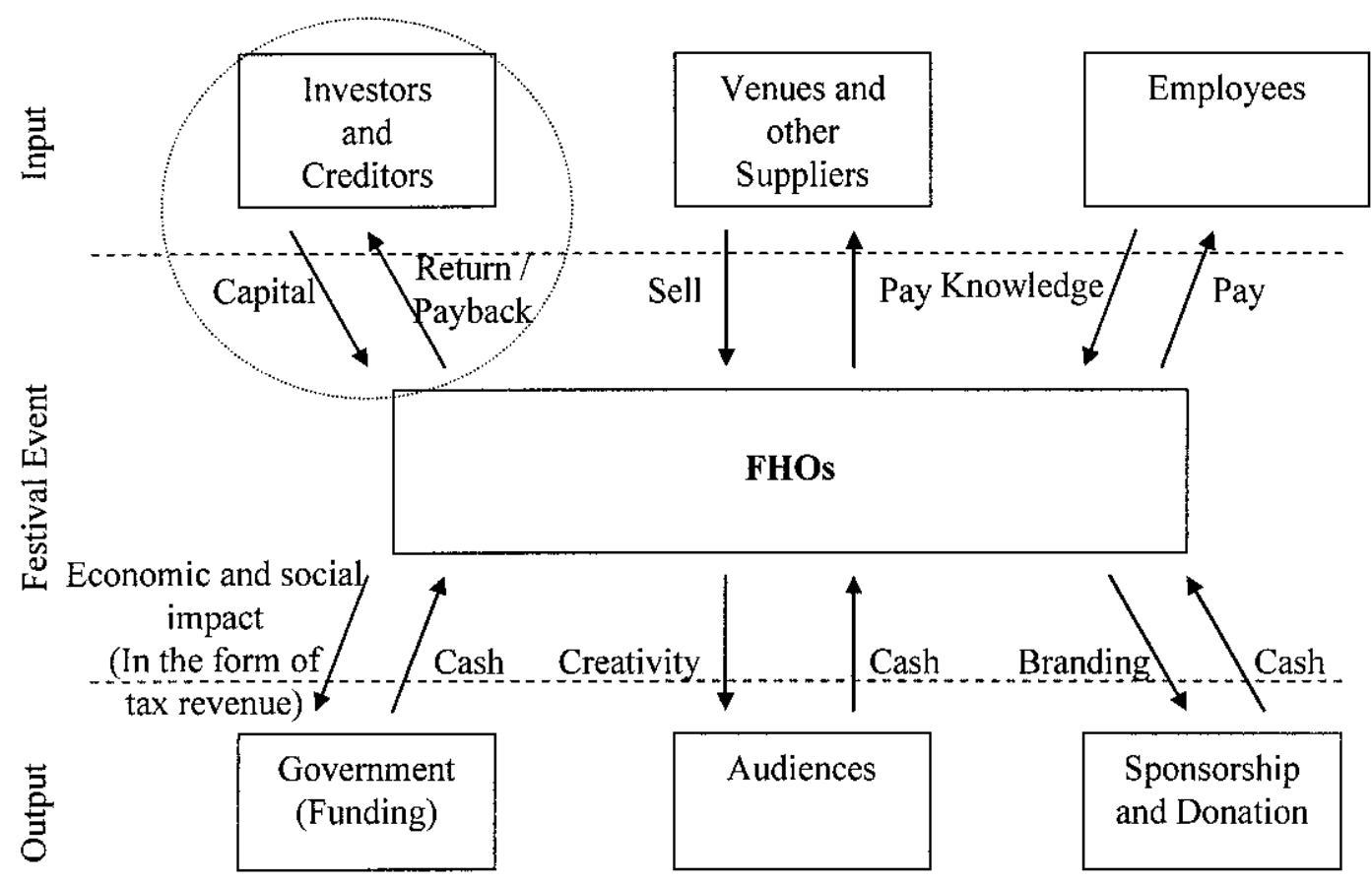

Figure 3. Lin-Stein-Goldblatt input-output model of festival organizations with potential investors and creditors. 


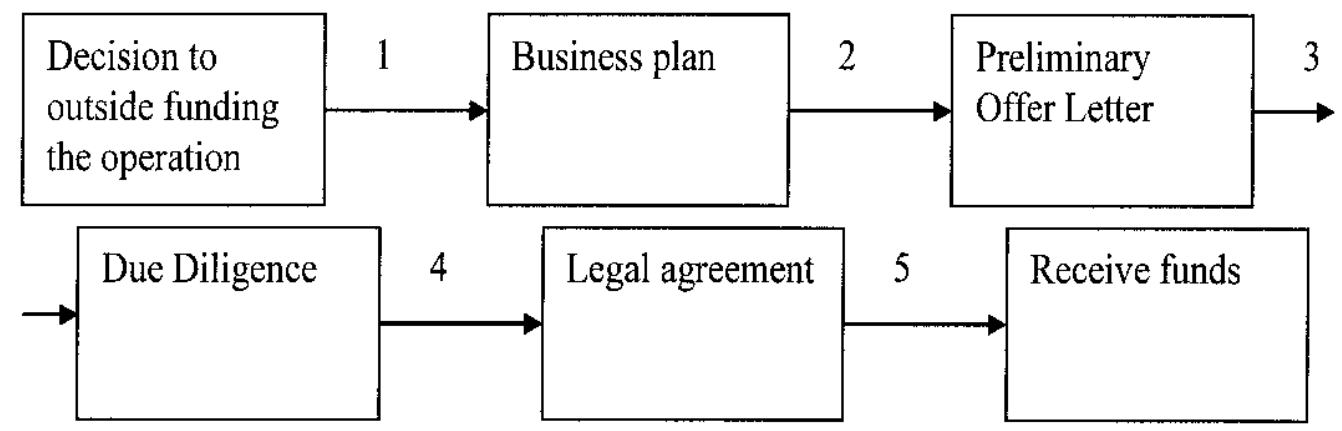

Figure 4. Process of securing finance from banks and venture capital firms.

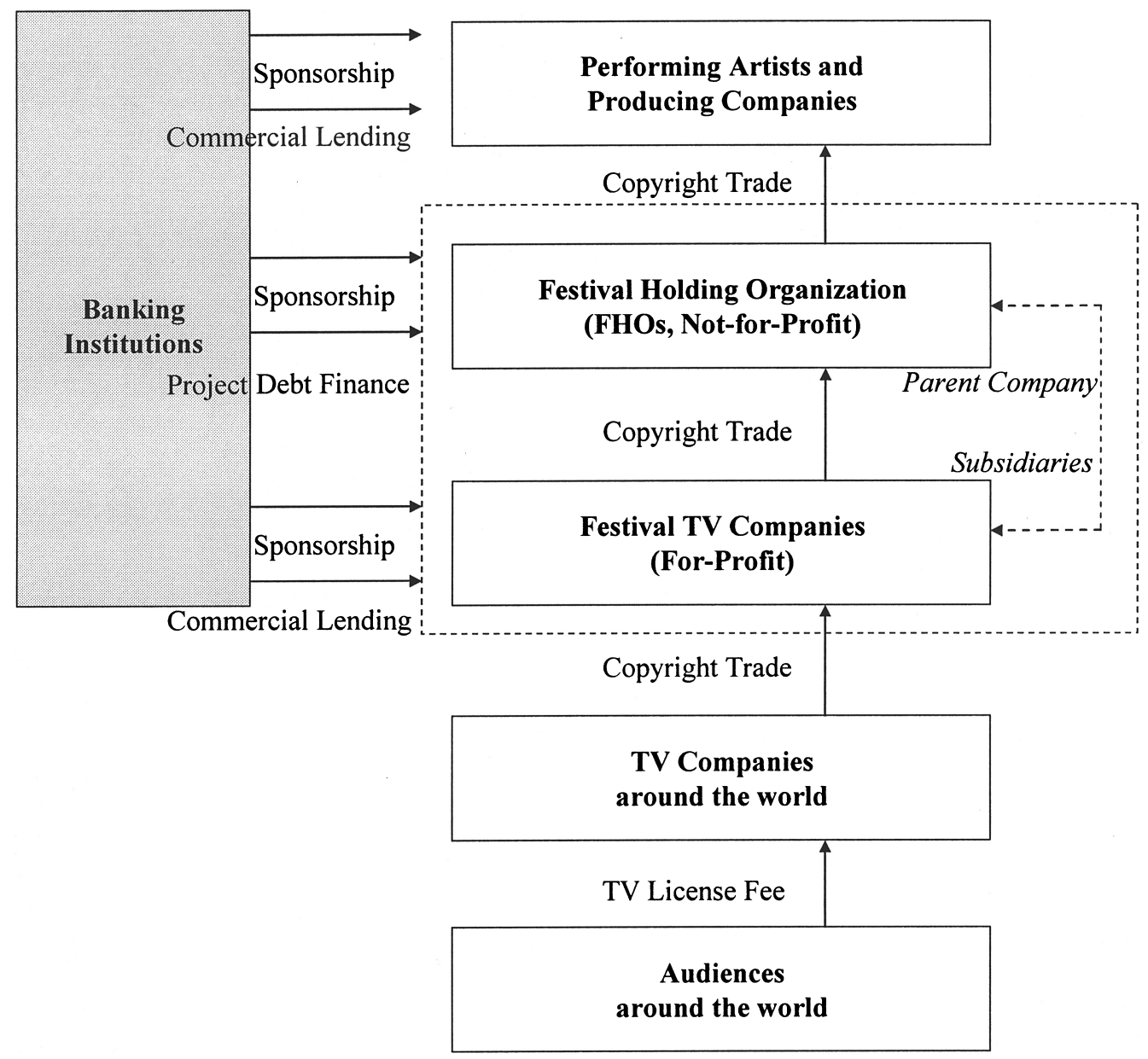

Figure 5. Potential financing structure in festival industry under copyright trading. 


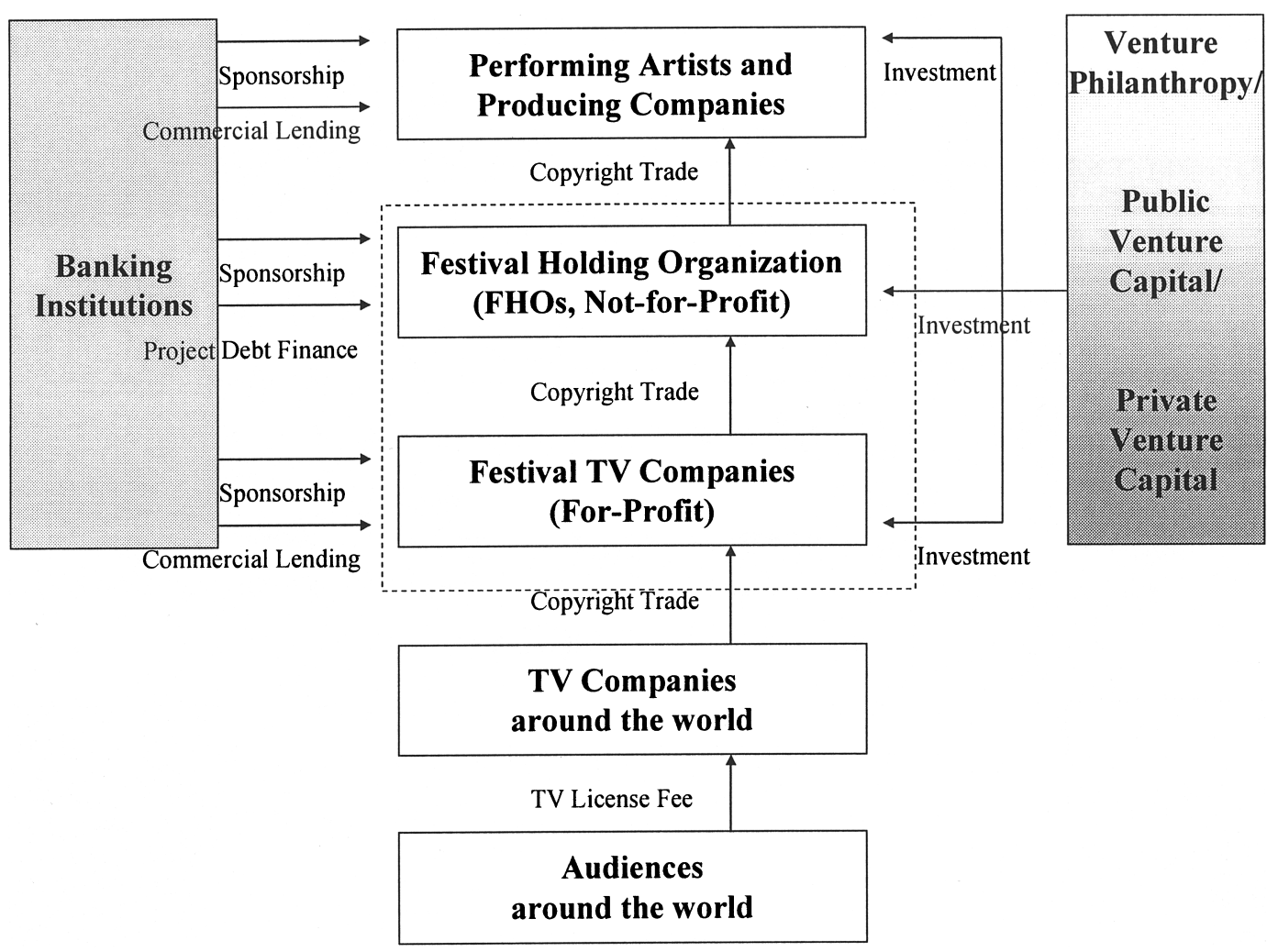

Figure 6. Lin-Stein-Goldblatt debt and equity finance structure in festival industry under copyright trading.

manager should ask the basic question "Why do we require outside funding for our festival holding organization?" There may be several different answers to this question, for example, the current level of financing is not enough to bring forward innovative products or services, or it could be that the past financing resources are diminishing (e.g., government funding or sponsorship). Other reasons could include issues of physical development, temporal shift, displacement, or issues of additionality. After answering this question it is necessary for the festival manager to focus upon ways of obtaining the financial resources.

After the decision has been made to fund the business externally, it is necessary to create a detailed business plan as depicted in step 1 of Figure 4. The business plan is the main "selling" document and the first impression given by the festival holding organization to the principal. The business plan usually contains the following main elements: cash flow statements, balance sheets, and income statements (including a business ratio of different input and output factors). Lady Rice states that FHOs' have a different financial planning and reporting cycle as compared to other businesses. She further suggests that "a festival must plan many years in advance to achieve their artistic goals, that is not least because most festivals run on an annual cycle, whereas, a traditional business may be able to have a more short term planning cycle" (Lady Rice, personal communication, August 19, 2009).

The festival manager must also provide a detailed analysis of the business, trading conditions, competitor analysis, and a plan for the future of how the investor may expect to realize the value of investment (Bartlett, 1988; Sherman, 2005). The festival manager has to identify appropriate principals who will carefully review the business plan. If the principal agrees to support the festival 


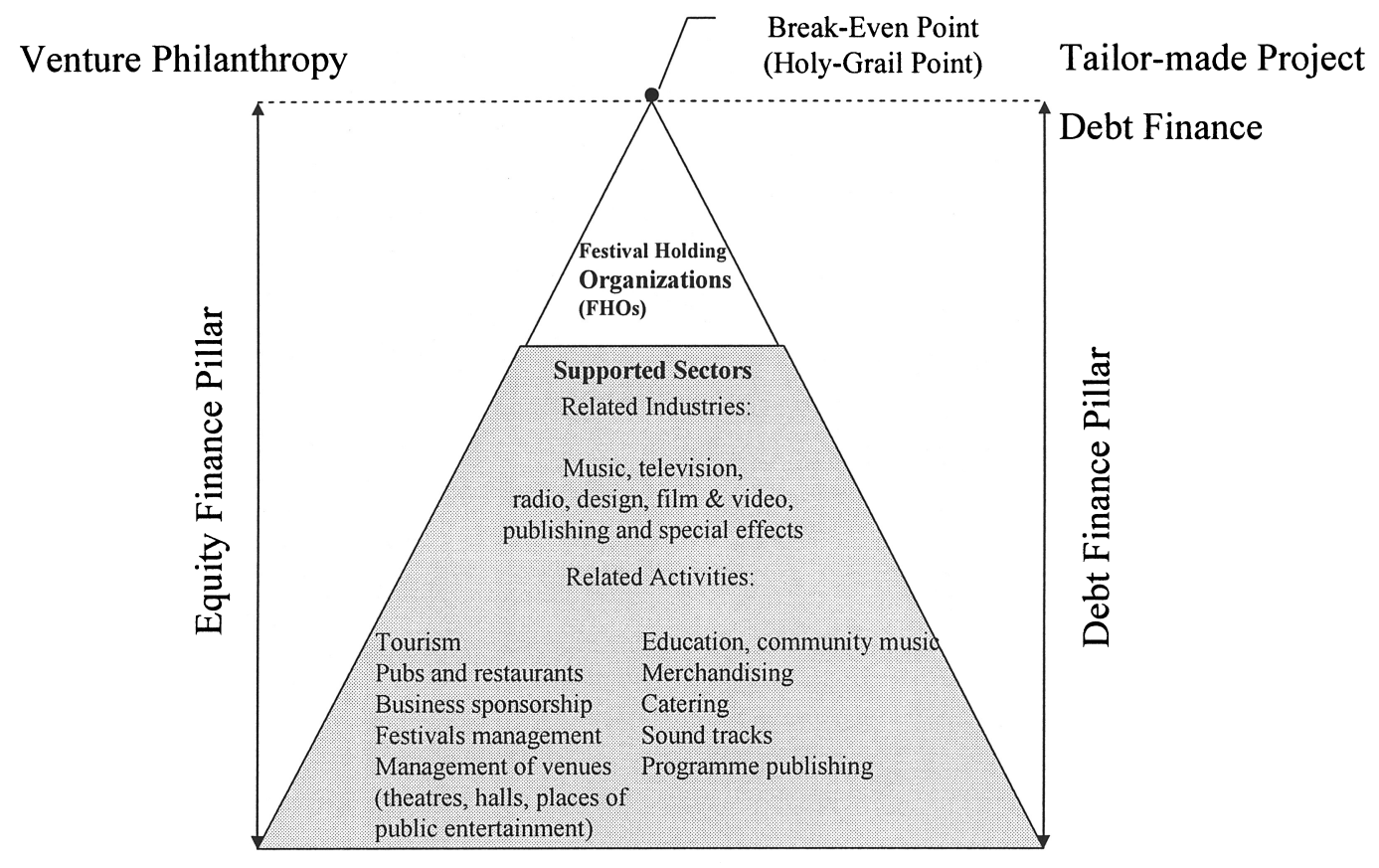

Venture Capital

General Lending

Figure 7. Lin-Stein-Goldblatt financing pillars for cultural festival industry ecology.

with funds, then both parties will sign a preliminary offer letter.

This signifies that both parties intend to execute a full contract later as shown in step 2 of Figure 4. In this step the banks or venture capitalists search for an external investor. After receiving the preliminary letter, the principal will check the FHO's representation through a process entitled due diligence. This means that the principal will carefully scrutinize the festival business situation and the risks and rewards as shown in step 3 of Figure 4. The principals will then decide to lend money, invest, or support the FHOs.

Finally, a binding legal agreement will be developed to be presented to the festival manager and the principal (Step 4). After signing the legal agreement, the FHO will receive the money and the principal will exit the business as shown in step 5 of Figure 4. As the entire process may take between 3 weeks and 6 months or more, it is necessary for the festival manager to consider the time frame in the scheduling of the festivals to finance its operations (Bloomfield 2005; Timmons, Spinelle, \& Zacharakis, 2004).

There are several risks and rewards when principals consider investing in festival organizations: 1) it is valuable to first investigate the types of risk that are present when evaluating a new business deal, 2) it is important to understand the risk after paying the money to the FHO, 3) it is crucial to understand the potential rewards for the principal.

In an initiation of a new investment (as depicted in Fig. 4) there are three main types of risk for the principals to carefully examine, especially in the due diligence section of the assessment, to minimize their future risks. These risks include technology risk, team risk, and market risk.

The technology risk requires venture capitalists to check the assets (see also Fig. 3, the Input-Output model, especially the input part) of the FHO and their property rights and the liquidity of their assets. It is necessary for the principal to know if the team (people/leaders) of the festival manage- 
ment will make the deal successful (team risk). The market risk implies future growth potential on the part of the festival within the current and future market conditions (Shanley, 2004).

After the FHO receives the financial investment, the main risk for the principal is if the FHO will experience a degree of failure, such as going into administration or declaring bankruptcy. However, if the FHO is growing and successful, the principal should receive a fair level of return for their investment.

Barriers of the Financial Capital From Banks and Venture Capitals to Festivals

There are several barriers FHOs may experience before receiving any financial capital from banks and VCs. The first barrier is the charity status of most FHOs. This is one of the reasons why
FHOs may choose not to seek finance from banks and $\mathrm{VCs}$, rather than being prevented from using these sources. Lady Rice (personal interview, August 19, 2009) recommends that not-for-profit firms such as festival holding organizations should not be solely grant dependent. She says that banks could provide financial support for festivals through traditional loans, although she has not been aware if any lending officer in her organization has investigated the financial statements of festivals. It has also been suggested that these financial enablers may help not-for-profit organizations "to grow, bridge a gap in funding, or support a fundraising drive" (National Council for Voluntary Organisations [NCVO], 2006, p. 16).

The second barrier requires festivals to improve their financial and management transparency in order to deal with the possible issue of asymmetric

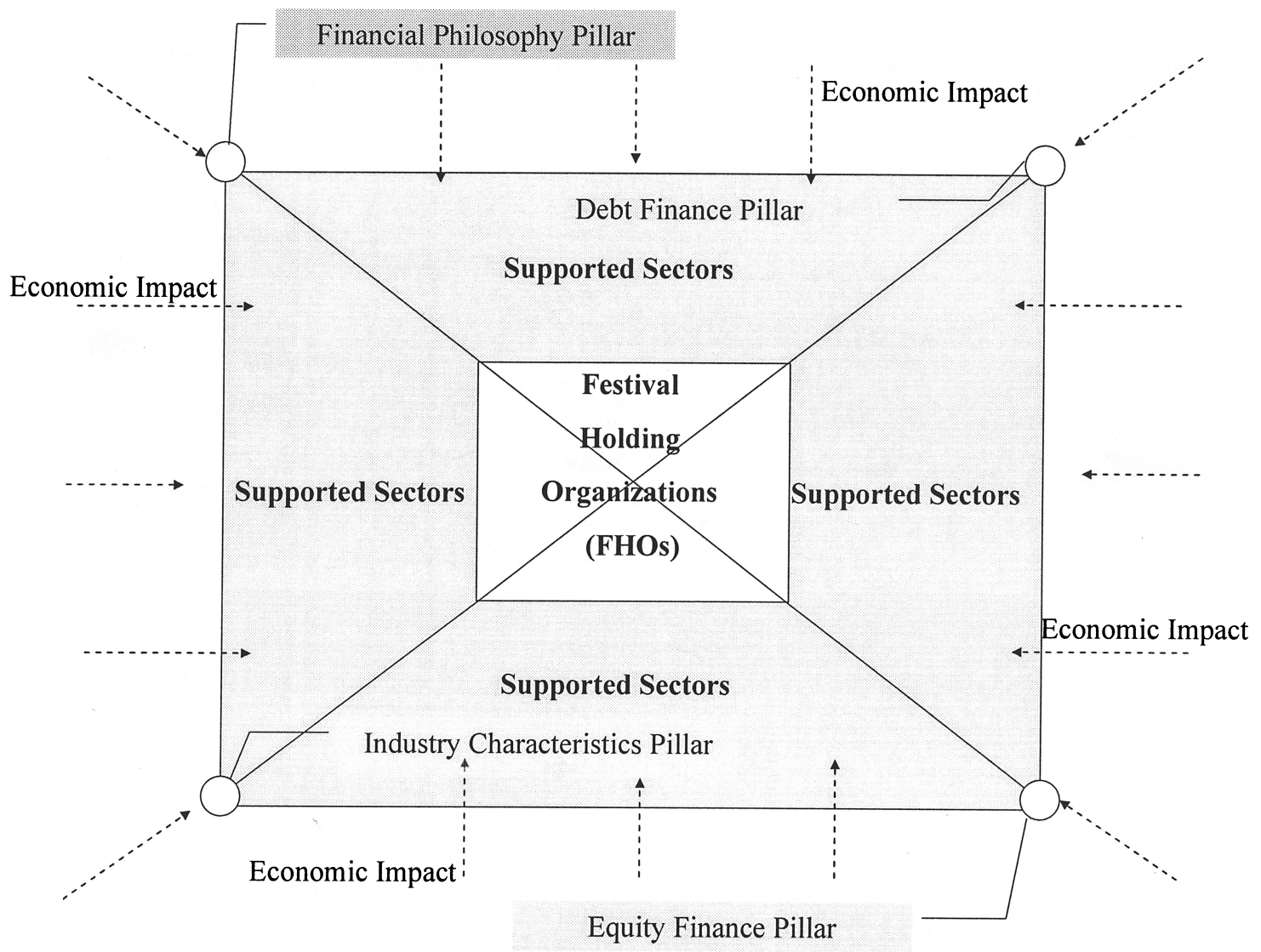

Figure 8. Lin-Stein-Goldblatt cultural festival industry solar panel effect characteristics. 
information between festivals and their potential creditors and investors. Lady Rice (personal interview, August 19, 2009) states that FHOs are not generally required by their governance structure to provide financial reporting each quarter and most festivals run on an annual cycle. This makes them atypical for most business financing from traditional organizations such as banks.

In addition, there is an issue of a lack of adequate tangible or intangible assets for securing debt in the process of arranging debt financing between banks and FHOs. In order to provide potential solutions for the situation, the definition of creative industries provided by the UK Government is useful: "those industries which have their origin in individual creativity, skill, and talent and which have a potential for wealth and job creation through the generation and exploitation of intellectual property" (DCMS, 2001, p. 5). Cultural festivals, such as the Edinburgh Festival Fringe and EIF, as showcases for performing artists, do not typically own part of or have sole ownership of the intellectual property of the performances they present. This phenomenon may be one of the main reasons why FHOs are restricted in terms of providing collateral or demonstrating equity as normally required by traditional finance organizations.

However, there appears to be a paradigm shift among the festivals in Edinburgh. In spring 2009, Festivals Edinburgh, the umbrella body of major festivals in Edinburgh announced its intention of creating an Internet television channel for selling the live festival experience to the world ("City Festivals," 2009). This strategy will not only allow the festivals to market their products worldwide but will also provide a cooperative opportunity for financiers to maintain a guaranteed rate of return. However, a guaranteed rate of return would be difficult to achieve in a not-for-profit and break-even organization.

As depicted in Figure 5, this model creates a potential business and cooperation model for closing the assets gap in order to arrange loans between banks and festivals. In Figure 5, the FHO plays a central role which is in charge of arranging shows and performances and securing broadcasting rights from performers and their production companies. Festivals' TV companies represent po- tential for-profit subsidiaries of the FHO who then purchase the broadcasting rights from the not-forprofit parent company. Through creating positive cash flows under copyright trading, three potential new business transactions may be introduced within the festival industry ecology (see Fig. 1): commercial lending between banks and performers or production companies; project debt finance between banks and the FHO; commercial lending between banks, and for-profit Festival TV Companies.

This new financial model may provide one future solution for the cooperation between banks and the festival industry, but also has the potential for solving the issue of the lack of a proper ROI between venture capitalists and the festival industry. Moreover, the structure of the separate, but dependent, FHO and its for-profit subsidiaries may reconcile the difference in risk preference between them and potential creditors and investors. Nevertheless, for not-for-profit FHOs, Lady Rice (personal interview, August 19, 2009) suggests that there could be emerging a new form of $\mathrm{VC}$, namely venture philanthropies (VPs), which may also have a potential role to play in closing the funding gap.

\section{Venture Philanthropy for Festivals}

Venture philanthropy (VP) represents a third sector approach that adapts some of the principles of venture capital with the characteristics of high engagement, multiyear support and capacity building is an approach to invest in organizations that provide public benefit (John, 2008). The length of VP's investment in each organization may last 5-10 years or more. This is much longer than most other funding models of this kind (Inspiring Scotland, 2009). This will allow the beneficiary to deliver its work in a much better strategic way.

The VP can also provide hands-on management advice to support charitable ventures and build close relationships without taking control of the venture. In some cases rigorous performance monitoring will be implemented in order to confirm the maximum return is achieved, and an exit strategy will be set up at the beginning of the initiative; both of these tactics are adapted from commercial investment funds. For example, Inspiring Scotland has been regarded as one of the biggest and bold- 
est VPs in the UK, and its aims are to make the beneficiary charity ready to be invested in and to improve its sustainability (Inspiring Scotland, 2009).

Lady Rice (personal interview, August 19, 2009) suggests that VP as well as traditional VC financing would work for festivals. In addition, there is also the possibility of third-party intermediaries to provide other sources of financing. As the Chair of the Edinburgh Festivals Forum, Lady Rice recognizes that festivals have different financing needs and schemes, and the model of VP is currently used primarily for social-related organizations, such as those promoting social cohesion within a community. "Venture Philanthropy is not like traditional government grants in that the targets are different. With government it may be the footfall they are seeking. With a VP, it is to promote organizational or societal change" (Lady Rice, personal interview, August 19, 2009).

There are potentially some opportunities for fusion through investing in different kinds and stages of festival holding organizations. One example could be to create a potential equity finance model for the festival industry as shown in Figure 6. In this model, the VP approach could be implemented by the festivals that focus primarily on benefits for the social sector or are young and vulnerable. However, private VC organizations may by contrast prefer to invest in commercial and mature festival holding organizations. Fusion investors such as public VCs may be able to bridge this gap in certain conditions. Combined with Figure 5 , a completed debt and equity finance model in the festival industry is presented with the addition of cash flow that is created through future copyright trading.

\section{Conclusions and Recommendation}

Many organizations within the festival industry are financially vulnerable due to the global economic crisis and the historically unpredictable and narrow sources of funding. A system of financing pillars to support the cultural festival industry ecology has been developed through this investigation and is summarized in Figure 7. With their not-for-profit status, some FHOs may prefer to seek funding from VP rather than VC in equity finance. Furthermore, customized project debt fi- nance may be developed to fit the unique requirements of not-for-profit FHOs in place of the general lending model in debt finance.

Furthermore, if Figure 1 is combined with Figure 7, a new three-dimensional pyramid system of festival industry ecology is created with four pillars: the financial philosophy pillar, the industry characteristics pillar, the equity finance pillar, and the debt finance pillar. A vertical view of the pyramid system shown in Figure 8 reveals that the scale of the supported sector within the festival industry is much larger than the FHOs. Therefore, the comparatively larger measure of the areas of the supported sector function in a similar way to solar panels that absorb and accumulate most of the positive economic impact (or sunshine) which is stimulated by the festival holding organizations within the system. The three-dimensional pyramid system may advance the overall financial understanding and potential of the festival industry, especially for potential creditors and investors.

In addition, Lady Rice states that FHO board development is critically important for festival organizations, as many board members are not familiar with the financing needs of these organizations (Lady Rice, personal interview, August 19, 2009). For example, within Lloyds TSB, after conducting a board development program for the Edinburgh International Book Festival, Lady Rice believed it had been highly successful. The concept of board development may help FHOs to improve transparency for their current and future financial stakeholders to facilitate funding opportunities.

FHOs should also increase their focus on developing self-owned intellectual property in order to strengthen their overall balance sheet to attract future funding sources.

\section{Future Research}

This research represents a preliminary analysis of alternative financing streams for festivals. However, additional research is needed to further advance this field of inquiry. For example, future researchers may wish to examine how FHOs may organize, schedule, collect, and publish financial information to provide a stronger case for funding from banks and venture capital organizations. Additionally, future researchers may wish to examine 
how banks, venture capitalists, and venture philanthropic organizations make their funding decisions in the cultural sector as compared to traditional business sectors. Finally, a longitudinal analysis of how the FHOs' financial performance may be advanced, improved, or even transformed through the use of alternative funding opportunities such as those suggested in this study.

\section{References}

AEA Consulting. (2006). Thundering hooves: Maintaining the global competitive edge of Edinburgh's festivalsfull report. Retrieved Octorber 18, 2009, from http:// www.scottisharts.org.uk/1/information/publications/100 3373.aspx

Allen, J., O'toole, W., Harris, R., \& McDonnell, I. (2005). Festival and special event management (3rd ed.). Milton, Qld: Wiley.

Bartlett, J. W. (1988). Venture capital: Law, business strategies, investment planning. New York: John Wiley \& Sons.

Benjamin, G. A., \& Margulis, J. B. (2005). Angel capital: How to raise early-stage private equity financing. New Jersey: John Wiley \& Sons.

Blackburn, R. A., Stokes, D., \& Wilson, N. (2001). Banking on a hit: The funding dilemma of Britain's music business, executive summary. London, UK: DCMS.

Bloomfield, S. (2005). Venture capital funding: A practical guide to raising finance. London: Kogan Page.

Carlsen, J., Ali-Knight, J., \& Robertson, M. (2008). Access-a research agenda for Edinburgh festivals. Event Management, 11, 3-11.

Carrell, S. (2009, September 1). Edinburgh festival fringe sales benefit from recession gloom. The Guardian.

Carrell, S. (2009, January 10). Edinburgh Fringe may seek $€ 600,000$ bail-out. The Guardian.

Caves, R. E. (2000). Creative industries: Contracts between art and commerce. London: Harvard University Press.

Cochrane, J. H. (2005). The risk and return of venture capital. Journal of Financial Economics, 72(1), 3-52.

Dana, L. P. (2008). Handbook of research of ethnic minority entrepreneurship: A co-evolutionary view on resource management. Glos: Edward Elger.

Department for Culture, Media and Sport. (2001a). Creative industries mapping document (2nd ed.). London: Author.

Department for Culture, Media and Sport. (2001b). Reports on the creative industry finance conference: Good practice in financing creative businesses. London: Author.

Dibdin, T. (2008, December 16). Edinburgh fringe's $€ 250,000$ bail out eases box office system woes. The Stage News.

City festivals to get Online TV channel. (2009, March 18). Edinburgh Evening News.

Edinburgh International Festival. (2006). Edinburgh Inter- national Festival society reports and financial statements. Edinburgh: Festival Fringe Society Limited.

Edinburgh International Festival. (2008). Annual review.

Edinburgh: Edinburgh International Festival Society.

Edinburgh International Festival. (2009). The official website of the Edinburgh International Festival. Retrieved October 18, 2009 from http://www.eif.co.uk/

Edinburgh Military Tattoo. (2004). The Edinburgh Military Tattoo limited reports and financial statements. Edinburgh: Author.

Edinburgh Military Tattoo. (2006). The Edinburgh Military Tattoo limited reports and financial statements. Edinburgh: Author.

Edinburgh Military Tattoo. (2009). The official website of the Edinburgh Military Tattoo. Retrieved October 18, 2009 from http://www.edintattoo.co.uk/

Edinburgh Military Tattoo Charities. (2001). The Edinburgh Military Tattoo (charities) limited reports and accounts. Edinburgh: Author.

Eisenhardt, K. M. (1989). Agency theory: An assessment and review. Academy of Management Review, 14(1), 57-74.

Fama, E. F., \& Jensen, M. C. (1983). Separation of ownership and control. Journal of Law and Economics, 26(2), 301-325.

Festival Fringe Society Limited. (2004). Festival Fringe Society limited financial statements. Edinburgh: Author.

Festival Fringe Society Limited. (2006a). Annual report. Edinburgh: Author.

Festival Fringe Society Limited. (2006b). Festival Fringe Society limited financial statements. Edinburgh: Festival Fringe Society Limited.

Festival Fringe Society Limited. (2009). The official website of the Edinburgh Festival Fringe. Retrieved October 18, 2009 from http://www.edfringe.com/

Finkel, R. (2009). A picture of the contemporary combined arts festival landscape. Cultural Trends, 18(1), 3-21.

Finkel, R., Goldblatt, J., \& Lin, K. (2009). An exploratory study to identify sustainable funding alternatives for cultural events in Edinburgh and Glasgow, special report, 1. Edinburgh, UK: The International Centre for the Study of Planned Event (ICSPE), Queen Margaret University.

Florida, R. (2002). The rise of the creative class: And how it's transforming work, leisure, and everyday life. New York: Basic Books.

Getz, D. (2002). Why festivals fail. Event Management, 7, 209-219.

Getz, D., Andersson, T., \& Larson, M. (2007). Festival stakeholder roles: Concepts and case studies. Event Management, 10, 103-122.

Goldblatt, J. (2008). Special events: The roots and wings of celebration. (5th Ed.) Hoboken, NJ: John Wiley \& Sons.

Grossman, S. J., \& Hart, O. D. (1983). An analysis of the principal-agent problem. Econometrica, 51(1), 7-45.

Inspiring Scotland. (2009). The official website of Inspiring 
Scotland. Retrieved October 18, 2009 from http:// www.inspiringscotland.org.uk/

Jensen, M. C., \& Meckling, W. H. (1976). Theory of the firm: Managerial behavior, agency costs, and ownership structure. Journal of Financial Economics, 3(4), 305360.

John, R. (2008). A guide to giving (3rd ed., pp. 35-39). London: Association of Charitable Foundations.

Jones Economics. (1996). Edinburgh Festivals economic impact study: Final report. Edinburgh: Author.

Kenney, M., Haemmig, M., \& Goe, W. R. (2008). Venture capital. In J. T. Machers \& D. C. Mowery (Eds.), Innovation in global industries (pp. 313-340). Washingtonm DC: National Academy of Sciences.

Lin, K. (2008). A quantitative analysis of the public grants and the time factor involved in reducing the financial risk to the festivals belonging to Festivals Edinburgh. Master's thesis, Queen Margaret University, Edinburgh, UK.

Miller, E. (1996). The Edinburgh International Festival 1947-1996. Aldershot: Scolar Press.

National Council for Voluntary Organizations. (2006). Introductory pack on funding and finance. London: Author.

National Council for Voluntary Organizations. (2009). The official website of NCVO. Retrieved October 18, 2009 from http://www.ncvo-vol.org.uk/

Reid, G. C. (1998). Venture capital investment: An agency analysis of practice. London: Routledge.
Ross, A. S. (1973). On the economic theory of agency and the principal of similarity. In M. Balch et al. (Eds.), Essays on economic behavior under uncertainty (pp. 215-237). Amsterdam: North Holland.

Shanley, R. P. (2004). Financing technology's frontiers: Decision-making models for investors and advisors (2nd ed.). New Jersey: John Wiley \& Sons.

Sherman, A. J. (2005). Raising capital: Get the money you need to grow your business. New York: AMACON.

Spremann, K. (1987). Agent and principal. In G. Bamberg, \& K. Spreman (Eds.), Agency theory, information, and incentives (pp. 3-37). Berlin: Springer-Verlag.

Stiglitz, J. E. (1974). Risk sharing and incentives in sharecropping. Review of Economic Studies, 41(126), 219255.

Timmons, J. A., Spinelle, S., \& Zacharakis, A. (2004). How to raise capital: Techniques and strategies for financing and valuing your small business. New York: McGrawHill.

Wilson, R. (1968). The theory of syndicates. Econometrica, 36(1), 119-132.

Winton, A., \& Yerramilli, V. (2008). Entrepreneurial finance: Banks versus venture capital. Journal of Financial Economics, 88(1), 51-79.

$\mathrm{Wu}, \mathrm{S}$. (2002). A study of constitution of "International Festival" in Taiwan (in Chinese). Master's thesis, NanHua University, Taiwan, Republic of China. 
